wing-coverts and scapulars having the upper vanes deep black, margined and lined with rufous, the lower vanes grayish freckled, and blotched with black, while the shafts are dull whitish.

Tertiaries on their upper vanes with broad fulvous margins; feet and legs pale; bill black; irides chocolate-brown.

Length 8 inches, wing 5 inches, tail 2 inches, tarsus $1 \frac{3}{10}$ ths, ridge of bill $\frac{6}{10}$ ths, from angle of mouth $\frac{7 \frac{1}{10}}{10}$ hs.

This appears to be an undescribed species of that group of quails which so much resemble our common $O$. virginianus. The present however is readily distinguished from that species by its much longer bill and very short tail, as well as its general markings, particularly beneath; the breast and sides being of a plain fawn-colour, or pale rufous. The only specimen from which I describe was brought from Jalapa, Mexico, by Mr. Pease. It does not appear to be quite adult, and the markings about the head and throat may be somewhat different in the old bird; still however its characters are sufficiently marked. Judging from description, it must very nearly resemble the $\boldsymbol{O}$. pectoralis of Gould; but besides the difference of markings, he makes no mention of that species having a crest. The length of the bird, as well as of the wing, is in this also just one inch greater, which would hardly be the case in a young bird.-Proceedings of the Academy of Natural Sciences of Philadelphia, vol. iv. p. 77.

\title{
Descriptions of two new Californian Quadrupeds.
}

\section{By William Gambel, M.D.}

Dipodomys agilis. Colour above yellowish brown, mixed with dusky; beneath pure white, extending half-way up the sides. Head elongated, tapering from the ears to a sharp point. Ears nearly round, sparsely hairy. Eyes large, dark brown. A large pouch on each side of the head, opening externally on the cheeks. Both hindand fore-feet with four toes and the rudiment of a fifth. The hindlegs very long and strong. Tail very long, slender, covered with hair, and ending in a pencillated tuft.

Length $10 \frac{1}{2}$ inches, including the tail, which is $6 \frac{1}{2}$ inches.

$$
\text { Dental system: Teeth }\left\{\begin{array}{c}
10 \text { upper. }\left\{\begin{array}{l}
2 \text { incisors. } \\
8 \text { molars. }
\end{array}\right. \\
10 \text { lower. }\left\{\begin{array}{l}
2 \text { incisors. } \\
8 \text { molars. }
\end{array}\right.
\end{array}\right.
$$

In the upper jaw the incisors are divided by a longitudinal furrow.

This beautiful Jerboa-like animal is an abundant inhabitant of the vineyards and cultivated fields of the Pueblo de los Angeles, Upper California.

Like the other pouched animals, it forms extensive burrows, traversing the fields in different directions, and is only dislodged during the process of irrigation. They leap with surprising agility, sometimes the distance of ten feet or more at a spring, and are difficult to capture.

Mus californicus. Dark gray, lighter about the head and shoulders, above tinged with light brown, on the sides almost fulvous, 
beneath almost white. Fore-feet with four toes and the rudiment of a fifth. Hind-feet with five toes. Tail nearly 5 inches in length, pretty thickly covered with short rigid hairs. Head acutely conical; ears large, rounded, thin, sparsely hairy, 1 inch in length and $\frac{5}{8}$ ths in breadth. Length of the body $4 \frac{3}{4}$ inches. Old male : bristles of the nose $2 \frac{1}{2}$ inches.

I captured but a single specimen of this species in a field near Monterey, Upper California, which, with those of the former, I had the misfortune to lose.-Ibid.

\section{METEOROLOGICAL OBSERVATIONS FOR FEB. 1849.}

Chiswick.-February 1. Frosty : foggy : rain. 2. Drizzly: hazy : rain. 3. Hazy and damp : densely overcast. 4. Overcast. 5. Very fine : overcast. 6. Hazy : densely overcast. 7. Overcast. 8. Very fine : clear. 9. Fine : overcast. 10. Overcast : clear at night. 11. Clear : very fine : barometer unusually high : clear and frosty at night. 12. Frosty and foggy : fine : clear and frosty. 13. Dense fog: fine at noon: foggy. 14. Foggy : fine. 15. Very fine. 16. Foggy : clear at night. 17. Frosty: exceedingly fine. 18. Overcast. 19. Overcast : fine. 20. Slightly overcast : cloudy : rain. 21. Cloudy and fine : rain. 22, 23. Fine. 24. Drizzly : rain : lightning in the evening: densely overcast. 25. Hazy : boisterous, with rain and thunder : constant heavy rain at night. 26. Cloudy and fine: frosty. 27. Frosty : cloudy and fine: clear. 28. Boisterous, with heavy rain.- On the 11 th the barometer was higher than it has ever been observed in this locality.

Mean temperature of the month ........................... $41^{\circ} \cdot 35$

Mean temperature of Feb. 1848 ............................... $49 \cdot 06$

Mean temperature of Feb. for the last twenty years ...... $40 \cdot 36$

Average amount of rain in Feb. ........................... 1.61 inch.

Boston.-Feb. 1. Fine. 2, 3. Foggy. 4, 5. Fine. 6, 7. Cloudy. 8. Fine: rain P.M. 9-12. Fine. 13. Foggy. 14-17. Fine. 18. Cloudy. 19. Cloudy: rain P.м. 20. Fine: rain p.M. 21. Cloudy. 22, 23. Fine. 24, 25. Cloudy. 26, 27. Fine. 28. Rain : snow A.M. and P.M.

Applegarth Manse, Dumfries-shire.-Feb. 1. Frost and snow : looking moist P.M. 2. Fog and drizzling all day. 3. Fog and drizzling. 4. Dull A.м. : drizzling rain P.M. 5. Still dull, but fair : cloudy and moist P.M. 6. Mild : cloudy : high wind P.м. 7. Rain during night: fair and clear. 8. Fair, but dull A.м. : rain P.M. 9. Fair early A.M. : rain at noon : rain P.M. 10. Fine morning : one shower : clear P.M. 11. Frost: fog : cleared P.M. 12. Fair: slight shower: cleared. 13. Frost A.M. : clear: rain P.м. 14. Fine spring day : dry throughout. 15. Fine : drying wind. 16. Frost: clear and fine: high wind P.M. 17. Fair and clear : storm of wind. 18, 19. Rain and wind. 20. Dull and moist. 21. Frost : rain and wind P.M. 22. Dull A.M. : came on storm, wind and rain. 23. Fair : slight frost : snow on hills. 24. Frost and snow : clear: freezing. 25. Hard frost : fine. 26. Very hard frost : hail-shower. 27. Hard frost. 28. Rain heavy : wind high.

Mean temperature of the month $41^{\circ \cdot 2}$

Mean temperature of Feb. 1848 $40 \cdot 1$

Mean temperature of Feb. for the last twenty-five years. $37 \cdot 3$

Rain in Feb. 1848 $5 \cdot 58$ inches.

Average amount of rain in Feb. for the last twenty years 2.04,

Sandwick Manse, Orkney.-Feb. 1. Clear: frost : cloudy. 2. Cloudy. 3. Bright : drizzle. 4. Bright: clear : hoar-frost. 5. Drizzle : rain. 6. Clear: cloudy. 7. Drizzle: cloudy. 8. Bright: hail, thunder and lightning. 9. Cloudy : damp. 10. Thunder and lightning: sleet-showers 11. Bright: cloudy. 12. Fine : clear : aurora. 13. Showers. 14. Rain. 15. Rain : drizzle. 16. Hazy : showers. 17. Cloudy : showers. 18. Showers. 19. Showers : aurora. 20. Snowshowers. 21. Frost : snow-showers. 22, 23. Snow : frost : aurora. 24. Snowshowers. 25. Snow-showers : clear: frost. 26. Snow-showers : clear : aurora. 27. Snow : fine : clear : aurora. 28. Rain: sleet-showers. 


\section{$2 \mathrm{BHL}$ Biodiversity Heritage Library}

Gambel, William. 1849. "Descriptions of two new Californian quadrupeds." The Annals and magazine of natural history; zoology, botany, and geology 3 , 318-319. https://doi.org/10.1080/03745485909494769.

View This Item Online: https://www.biodiversitylibrary.org/item/71826

DOI: https://doi.org/10.1080/03745485909494769

Permalink: https://www.biodiversitylibrary.org/partpdf/60289

\section{Holding Institution}

University of Toronto - Gerstein Science Information Centre

\section{Sponsored by}

University of Toronto

\section{Copyright \& Reuse}

Copyright Status: NOT_IN_COPYRIGHT

This document was created from content at the Biodiversity Heritage Library, the world's largest open access digital library for biodiversity literature and archives. Visit BHL at https://www.biodiversitylibrary.org. 